\title{
Reproductive Parasitism: Maternally Inherited Symbionts in a Biparental World
}

\author{
Gregory D.D. Hurst and Crystal L. Frost \\ Institute of Integrative Biology, University of Liverpool, Liverpool L69 7ZB, United Kingdom \\ Correspondence: g.hurst@liv.ac.uk
}

\begin{abstract}
Most species of insect, and many other plants and animals, carry maternally heritable microorganisms - viruses, bacteria, unicellular eukaryotes, and fungi that pass from a female host to her progeny. Maternal inheritance establishes a correlation between the fitness of symbiont and host female, which can select for the symbiont to contribute to host fitness. Nevertheless, its lack of transmission through male hosts places the symbiont in conflict with biparentally inherited nuclear genes. In this review, we first examine how this conflict is manifest in selection to promote the production and survival of infected female hosts and gametes. We then examine how the distorted population sex ratios that they produce may affect host reproductive ecology, and thus the intensity of other conflicts associated with sexual reproduction. Finally, we examine evolved host responses to symbiont manipulation. We argue that the unusual intensity of symbiont-host conflict generates extreme selection pressures that can drive changes in sex-determination systems, the basic pathway through which males and females are constructed.
\end{abstract}

B etween 1909 and 1932, Hubert Simmonds bred individuals of the great eggfly, Hypolimnas bolina, seemingly as a pet project to distract him from his daily work as an agricultural entomologist in Fiji. What Simmonds discovered, by accident, was the presence of a trait in which female butterflies produced only daughters. He found that many females in his population had this trait, such that few males were present in the wild. He could maintain his allfemale lines indefinitely, irrespective of the male used in the cross, and concluded that it was a trait acquired from the mother alone. Finally, he noted that half of the eggs laid by the female died during embryogenesis, and concluded that the all-female trait was associated with the death of sons (Simmonds 1923a,b, 1926, 1927, 1928, 1930). He had, by accident and very careful observation, discovered the first maternally inherited male-killing agent.

Simmonds's observation was the first of a number of cases of unusual maternally inherited traits. In 1941, Lewis built the first model of evolution under cytoplasmic inheritance, which recognized that male sterility in plants spread into populations much more easily when the trait was maternally inherited (Lewis 1941). In the same year, maternally inherited feminization of woodlice hosts was observed by Vandel (1941). The next 20 years saw numerous

Editors: William R. Rice and Sergey Gavrilets

Additional Perspectives on The Genetics and Biology of Sexual Conflict available at www.cshperspectives.org

Copyright (C) 2015 Cold Spring Harbor Laboratory Press; all rights reserved; doi: 10.1101/cshperspect.a017699

Cite this article as Cold Spring Harb Perspect Biol 2015;7:a017699 
records of maternally inherited male lethality in ladybird beetles and flies (Lus 1947; Shull 1948; Magni 1953; Cavalcanti et al. 1957; Malogolowkin 1958). Further, unusual cross-incompatibilities between members of different populations of Culex mosquitoes were also noted as having a maternally inherited basis (Laven 1951). Collectively, these traits have been termed "reproductive parasitism"-because the impacts on reproduction are deleterious to host fitness.

Later work in the "molecular genetics age" examined the cause of these traits. "Reproductive parasitic" behaviors in plants are commonly associated with mutations in the mitochondrial genome, but have recently also been ascribed to heritable fungi (Gorischek et al. 2013). Reproductive parasitism in animals is associated with a wide variety of microbial symbionts: viruses, bacteria, unicellular eukaryotes, and fungi that pass from a female to her progeny either inside eggs or through smearing on the outside of eggs followed by trophic acquisition (Terry et al. 2004; Nakanishi et al. 2008; Duron and Hurst 2013; Gorischek et al. 2013). Although many heritable microbes are simply "beneficial symbionts," reproductive parasitism of the type described above is widespread (and may be combined with beneficial impacts on the female host).

We first review the rationale underlying the selection for reproductive parasitic phenotypes, the mechanisms by which the manipulations are achieved, and the impact of the phenotypes on the symbiont's population biology. We then examine the impacts of reproductive parasitism on host reproductive ecology and other conflicts associated with reproduction. We then examine nuclear responses to the presence of heritable parasites, first for sex-ratio/sex-allocation distorters and then for incompatibility-inducing symbionts. We argue that reproductive parasites can create the strongest selective pressures observed in nature, and these will likely be associated with changes in reproductive systems. We speculate that these strong forces may be important in driving "unusual" evolutionary events, such as those underlying the evolution of sexdetermination systems.

\section{MANIFESTATIONS OF CYTOPLASM- NUCLEAR CONFLICT; POPULATION BIOLOGY OF REPRODUCTIVE PARASITES}

The selection for reproductive parasitic traits derives from the symbiont's uniparental (maternal) inheritance (Cosmides and Tooby 1981). Maternally inherited symbiont fitness depends solely on the symbiont's impact on the survival or production of female hosts. A symbiont that is purely maternally inherited will only spread if infected individuals on average produce more infected female offspring than uninfected hosts produce uninfected daughters. The "drive" that creates this increase in daughter production can simply be symbiont traits that increase the fitness of infected females over that of their uninfected counterparts. Indeed, many of these symbionts are beneficial in both sexes, providing "services" such as protection against natural enemies (Hamilton and Perlman 2013) or provision of anabolic capability (Moran et al. 2008). Notwithstanding this, drive can additionally (and not mutually exclusively [Himler et al. 2011]) be achieved through skewing sex allocation/sex ratio such that infected females produce more daughters. Alternately, the symbiont may leave males unharmed in terms of survival but modify male host gametogenesis, producing sperm that are modified to selectively eliminate uninfected zygotes. This phenomenon of cytoplasmic incompatibility promotes symbiont spread through selectively reducing the fitness of uninfected females. Altogether, these phenotypes represent cases of the wider phenomenon of intragenomic conflict, with the pattern of selection on uniparentally inherited elements differing from selection on nuclear genes with respect to sex allocation, sex ratio, and male fertility (Hurst et al. 1996).

The drive created by a symbiont must be sufficient to overcome any segregrational lossprogeny that fail to inherit them-and any direct physiological/pathological costs of carrying a symbiont. Theory predicts that symbionts with perfect transmission (no segregational loss) that can invade populations will, in a panmictic population, become fixed (Hurst 1991). Indeed, reproductive parasitic symbionts are 
known to infect all female individuals in some species (Stouthamer et al. 1990; Rigaud and Juchault 1992; Dyson and Hurst 2004). However, polymorphism of reproductive-parasite-carrying uninfected individuals is more common. Polymorphism is stabilized by three factors: (1) imperfect maternal inheritance, in which segregational loss prevents fixation of symbionts; (2) additional cost of symbiont carriage at high prevalence, for example, unmatedness of symbiont-carrying individuals (Groenenboom and Hogeweg 2002); and (3) evolution of host factors that affect the phenotype of the symbiont, for example, evolution of host suppressor genes.

The manipulation phenotypes above evolve because male hosts are a dead end for a maternally inherited symbiont. However, some symbionts can combine maternal transmission with infectious transmission, such that male hosts represent a viable source of onward infection. In a number of cases, female hosts are used exclusively for maternal transmission and male hosts for onward infectious transmission. Infectious transmission through sons often occurs relatively late in host development and is associated with the death of male hosts. This discrepancy in timing has led to these examples being termed "late male killing," differentiating them from the more common embryonic male-killing interactions in which male death is not associated with infectious transmission (Hurst 1991).

Below we outline the three main manifestations of symbiont-host conflict (distortion of sex ratio/sex allocation, cytoplasmic incompatibility, and late male killing) in terms of mechanism, diversity, and population biology. For simplicity, we assume in our treatment of population biology that a symbiont has a single phenotypic impact on its host; the ramifications of contravening this assumption are discussed later.

\section{Distortions of Sex Ratio/Sex Allocation}

Maternally inherited symbionts in host species with separate sexes can spread either through biasing sex ratio to the production of daughters or, where there are antagonistic interactions be- tween male and female siblings, through killing males and reducing the intensity of competition suffered by infected females. Within hermaphroditic host species, biasing sex allocation to female reproductive function is favored where there is a trade-off between male and female reproductive activity. Altogether, four different distortions of sex ratio/sex allocations have evolved to aid symbiont/organelle spread.

\section{Feminization}

Symbiont-induced feminization is commonly observed in amphipod and isopod Crustacea (Bouchon et al. 1998) and also in mites, leafhoppers, and butterflies. The phenotype is the conversion of genetic males into phenotypic females (Table 1). In the best-studied case of symbiont-induced feminization, Wolbachia infection of Armidillidium vulgare, Wolbachia infection inhibits the formation of the male-determining androgenic gland during early development, and in so doing results in female development of individuals that are karyotypically male (ZZ, the species being female heterogametic). Converted females (neofemales) are reproductively functional although with occasional intersex properties. In mate-choice experiments, males prefer true females to feminized neofemales (Moreau et al. 2001).

The dynamics of feminizers depends on the transmission efficiency of the symbiont, the efficiency of feminization, and the host sex-determination system. In A. vulgare, feminization is efficient, but $10 \%$ of the progeny of a female fail to inherit the infection and develop as male (Rigaud and Juchault 1992). Because the species is female heterogametic, spread of the Wolbachia may be associated with fixation of the Z chromosome (Taylor 1990; but see Kobayashi and Telschow 2010). Indeed, $A$. vulgare populations exist in which all females are ZZ and carry feminizing Wolbachia, and population sex ratio is determined by the proportion of zygotes that do not inherit the microbe and develop as males. In other feminization systems, some males escape feminization, which may also stabilize population sex ratio and persistence (Moret et al. 2001). 
G.D.D. Hurst and C.L. Frost

Table 1. Incidence and mechanism of symbiont-induced feminization

\begin{tabular}{|c|c|c|c|}
\hline Symbiont & Host & Suggested mechanism & References \\
\hline \multirow[t]{3}{*}{ Wolbachia } & $\begin{array}{l}\text { Armadillidium } \\
\text { vulgare (Isopoda) }\end{array}$ & $\begin{array}{l}\text { Inhibition of androgenic gland } \\
\text { differentiation and/or inhibition } \\
\text { of androgenic hormone reception }\end{array}$ & Bouchon et al. 1998 \\
\hline & $\begin{array}{l}\text { Zyginidia pullula } \\
\text { (Hemiptera) }\end{array}$ & $\begin{array}{l}\text { Interference with male DNA methylation, } \\
\text { resulting in female imprinting patterns } \\
\text { across the genome }\end{array}$ & Negri et al. 2009 \\
\hline & $\begin{array}{l}\text { Eurema hecabe } \\
\quad \text { (Lepidoptera) }\end{array}$ & $\begin{array}{l}\text { Unknown; continuous during larval } \\
\text { development }\end{array}$ & $\begin{array}{l}\text { Hiroki et al. 2002; } \\
\quad \text { Narita et al. 2007 }\end{array}$ \\
\hline Cardinium & $\begin{array}{l}\text { Brevipalpus } \\
\text { phoenicis (Acari) }\end{array}$ & Feminization of haploid males & Weeks et al. 2001 \\
\hline Microspora sp. & $\begin{array}{l}\text { Gammarus duebeni } \\
\text { (Amphipoda) }\end{array}$ & $\begin{array}{l}\text { Inhibition of androgenic gland } \\
\text { differentiation }\end{array}$ & Jahnke et al. 2013 \\
\hline Nosema granulosis & & $\begin{array}{l}\text { Inhibition of androgenic gland } \\
\text { differentiation and potential partial } \\
\text { refractoriness to androgenic hormone }\end{array}$ & Jahnke et al. 2013 \\
\hline
\end{tabular}

\section{Parthenogenesis Induction}

In haplodiploid arthropods, males develop from unfertilized embryos. In Trichogramma wasps, manipulation of ploidy by microbes (doubling of chromosome constitution) leads to development of a female host from these unfertilized eggs (Table 2). Various mechanisms of parthenogenesis induction are now recognized, and three microbes (Wolbachia, Cardinium, and Rickettsia) are recognized as able to induce asexuality. Negative consequences of these symbionts on the overall reproductive success of infected females have been shown in some laboratory comparisons (Stouthamer and Luck 1993; Huigens et al. 2004), but field studies have found either little impact or a beneficial impact of symbiont presence on host fecundity (Segoli et al. 2013). Whichever is the case, the number of females produced by symbiont-infected females is always greater than for uninfected hosts, and thus the drive for an increase in the number of "transmitters" over "nontransmitters" is achieved.

Outside of haplodiploid taxa, the involvement of microbes in parthenogenesis is uncertain. There are certainly many parthenogenetic species that harbor symbionts (Koivisto and Braig 2003), and in some of these there is also evidence that antibiotic treatment alters the capacity of the host to reproduce (e.g., Timmer- mans and Ellers 2009). However, in nonhaplodiploid taxa, symbiont-free individuals do not produce males and antibiotic treatment may interfere with reproduction in other ways (e.g., because the symbionts are required for oogenesis as seen in Asobara tabida [Dedeine et al. 2001]) rather than being required for parthenogenesis, thus making definitively testing the role of symbionts in inducing parthenogenesis very difficult.

\section{Embryonic Male Killing}

Killing of zygotes that would develop as males is commonly observed, with multiple symbionts exhibiting this trait across a wide range of arthropods (Table 3). The mechanistic basis of male killing is also diverse, with male killing occurring via interference in male sex determination in some cases but as a result of host sexspecific symbiont responses in others.

The evolutionary advantage for male-killing behavior derives from the impact that death of males may have on the survival/reproduction of their sisters, who will share the symbiont infection through descent. In ladybird beetles, female larvae consume the eggs containing their dead male brothers, which increases their chance of survival (Elnagdy et al. 2011). In other cases, male and female siblings compete for re- 
Table 2. The diversity and mechanism of parthenogenesis induction by heritable symbionts

\begin{tabular}{|c|c|c|c|}
\hline Symbiont & Host & Suggested mechanism & References \\
\hline \multirow[t]{4}{*}{ Wolbachia } & $\begin{array}{l}\text { Trichogramma spp. and } \\
\text { Leptopilina clavipes } \\
\text { (Hymenoptera) }\end{array}$ & $\begin{array}{l}\text { Doubling of chromosome number } \\
\text { (haploid males) by failure of } \\
\text { chromosomes to segregate at the first } \\
\text { mitotic division }\end{array}$ & $\begin{array}{l}\text { Stouthamer and } \\
\text { Kazmer 1994; } \\
\text { Pannebakker } \\
\text { et al. } 2004\end{array}$ \\
\hline & $\begin{array}{l}\text { Muscidifurax uniraptor } \\
\text { (Hymenoptera) }\end{array}$ & $\begin{array}{l}\text { Doubling of haploid male chromosome } \\
\text { number via the fusion of two cell } \\
\text { nuclei following the initial mitosis }\end{array}$ & Gottlieb et al. 2002 \\
\hline & $\begin{array}{l}\text { Franklinothrips } \\
\quad \text { vespiformis (thrips) }\end{array}$ & Not known & Arakaki et al. 2001 \\
\hline & $\begin{array}{l}\text { Bryobia praetiosa and } \\
\text { Bryobia sp. (Acari) }\end{array}$ & $\begin{array}{l}\text { Apomictic parthenogenesis suggested, } \\
\text { whereby a lack of meiosis in eggs } \\
\text { means that doubling of chromosome } \\
\text { number is not required or else } \\
\text { automictic parthenogenesis with } \\
\text { central fusion }\end{array}$ & $\begin{array}{l}\text { Weeks and } \\
\text { Breeuwer } 2001\end{array}$ \\
\hline Cardinium & $\begin{array}{l}\text { Encarsia hispida } \\
\text { (Hymenoptera) }\end{array}$ & $\begin{array}{l}\text { Both automictic parthenogenesis } \\
\text { (chromosome doubling) and } \\
\text { feminization is required for a female } \\
\text { phenotype, but the mechanism for } \\
\text { these is unknown }\end{array}$ & Giorgini et al. 2009 \\
\hline $\begin{array}{l}\text { Rickettsia- } \\
\quad \text { transitional } \\
\text { group }\end{array}$ & Neochrysocharis formosa & $\begin{array}{l}\text { Occurs via achiasmatic apomictic } \\
\text { parthenogenesis, whereby a lack of } \\
\text { the creation of chiasma during egg } \\
\text { meiosis means that doubling of } \\
\text { chromosome number is not required }\end{array}$ & $\begin{array}{l}\text { Adachi-Hagimori } \\
\text { et al. } 2008\end{array}$ \\
\hline $\begin{array}{l}\text { Rickettsia- } \\
\text { bellii group }\end{array}$ & $\begin{array}{l}\text { Pnigalio soemius } \\
\text { (Hymenoptera) }\end{array}$ & Not known & Giorgini et al. 2010 \\
\hline
\end{tabular}

This list is exemplars, and many other examples exist.

sources, and the death of males reduces the intensity of competition suffered by female hosts (Koop et al. 2009). Finally, where females in a species suffer from inbreeding, male killing may be advantageous to the symbiont as a mechanism of promoting outbreeding (Werren 1987; but see Dannowski et al. 2009).

The magnitude of "drive" provided by male killing to the symbiont is inevitably less than that achieved through conversion of individuals from one sex to another. Under the most compliant biology, the viviparous harlequin pseudoscorpion Cordylochernes scorpioides, male killing reduces the intensity of resource competition in utero and infected females produce $26 \%$ more daughters, with these daughters also being larger in size than those from uninfected mothers (Koop et al. 2009). However, the drive achieved by male killers is likely to be commonly much lower than this. This low level of drive makes the frequency of male killers quite variable and sensitive to vertical transmission efficiency (Fig. 1). Although male killers with perfect maternal inheritance do obtain very high prevalence ( $>80 \%$ of females infected) (Jiggins et al. 2002; Dyson and Hurst 2004), imperfect maternal inheritance combined with modest benefits of male killing (and a lack of other benefits to female hosts) is associated with low prevalence. In many cases, male killers exist in $<20 \%$ of female hosts (Williamson and Poulson 1979; Hurst et al. 1993, 2000). At this prevalence, they may still create strong selection against their action, but ecological impacts are more limited.

In some host species, male killing has no obvious adaptive benefits. Examples of symbionts that appear to "accidentally" impact male 
G.D.D. Hurst and C.L. Frost

Table 3. The diversity and mechanism of male-killing symbionts in arthropods

\begin{tabular}{|c|c|c|c|}
\hline Symbiont & Host taxa & Suggested mechanism & References \\
\hline \multirow[t]{3}{*}{ Wolbachia } & $\begin{array}{l}\text { Ostrinia scapulalis } \\
\text { (Lepidoptera) }\end{array}$ & $\begin{array}{l}\text { Interference with the sex-specific } \\
\text { splicing of doublesex, with } \\
\text { mismatch between the } \\
\text { phenotypic and genetic sex } \\
\text { resulting in the death of males }\end{array}$ & $\begin{array}{l}\text { Sugimoto and } \\
\text { Ishikawa 2012; } \\
\text { Sugimoto et al. } 2012\end{array}$ \\
\hline & $\begin{array}{l}\text { Drosophila bifasciata } \\
\quad \text { (Diptera) }\end{array}$ & $\begin{array}{l}\text { Modulation of male chromatin } \\
\text { remodeling followed by } \\
\text { disruption of normal mitotic } \\
\text { spindle formation }\end{array}$ & Riparbelli et al. 2012 \\
\hline & $\begin{array}{l}\text { Various Lepidoptera, Diptera, } \\
\text { Coleoptera, and harlequin } \\
\text { pseudoscorpions }\end{array}$ & Unknown & $\begin{array}{l}\text { Hurst et al. 1999a; Zeh } \\
\quad \text { et al. } 2005\end{array}$ \\
\hline Rickettsia & $\begin{array}{l}\text { Ladybird and buprestid } \\
\text { beetles }\end{array}$ & Unknown & $\begin{array}{l}\text { Werren et al. 1994; } \\
\text { Lawson et al. } 2001\end{array}$ \\
\hline $\begin{array}{l}\text { Arsenophonus } \\
\text { nasoniae }\end{array}$ & $\begin{array}{l}\text { Nasonia vitripennis } \\
\text { (Hymenoptera) }\end{array}$ & $\begin{array}{l}\text { Inhibition of formation of maternal } \\
\text { centrosomes required for early } \\
\text { male development in } \\
\text { haplodiploids }\end{array}$ & Ferree et al. 2008 \\
\hline $\begin{array}{l}\text { Hamiltonella } \\
\text { related }\end{array}$ & $\begin{array}{l}\text { Cheilomenes sexmaculata } \\
\text { (ladybird beetle) }\end{array}$ & Unknown & $\begin{array}{l}\text { Majerus and Majerus } \\
2010\end{array}$ \\
\hline $\begin{array}{l}\text { Spiroplasma } \\
\text { poulsoni }\end{array}$ & $\begin{array}{l}\text { Drosophila melanogaster/ } \\
\text { Drosophila nebulosa }\end{array}$ & $\begin{array}{l}\text { Widespread apoptosis in male- } \\
\text { killed embryos; neural tissue is } \\
\text { inhibited from properly packing } \\
\text { into the neural chord and from } \\
\text { forming axons; male killing } \\
\text { requires the male form of the } \\
\text { dosage compensation complex }\end{array}$ & $\begin{array}{l}\text { Veneti et al. 2005; } \\
\text { Bentley et al. 2007; } \\
\text { Martin et al. } 2013\end{array}$ \\
\hline $\begin{array}{l}\text { Spiroplasma } \\
\quad \text { ixodetis group }\end{array}$ & $\begin{array}{l}\text { Various ladybird beetles, } \\
\text { Lepidoptera, and } \\
\text { Hemiptera }\end{array}$ & Unknown & $\begin{array}{l}\text { Hurst et al. 1999b; } \\
\text { Jiggins et al. 2000a; } \\
\text { Sanada-Morimura } \\
\text { et al. } 2013\end{array}$ \\
\hline
\end{tabular}

This list is exemplars, and many other examples exist.

fitness include protective Spiroplasma in aphids, which causes lethality in sexual males only (Simon et al. 2011), and Spiroplasma embryonic male killing in Danaus chrysippus, in which females lay solitary eggs, such that sibling-sibling interference is limited (Jiggins et al. 2000a). There are two possible logics underlying male lethality in these cases. First, male killing may be a relict following switch of a symbiont from a host in which male killing is adaptive into a novel host species in which it is not, but is nevertheless not disadvantageous. Second, it may derive from lack of selection against deleterious impacts observed in male hosts only (the "mother's curse" as discussed in Wade [2014]).

\section{Deviations in Sex Allocation in Hermaphrodite Plants}

Cytoplasmic male sterility (CMS), in which male reproductive function is selectively destroyed, is widespread in flowering plants. It is commonly associated with particular mitochondrial types, often associated with unusual open reading frames. Plant mitochondrial genomes commonly exist as minicircles that recombine. This intragenomic recombination creates new open reading frames, which are chimeric fusions, a fraction of which induces male sterility. The mechanism of CMS is known in a number of cases (Kubo et al. 2011). Typically, 


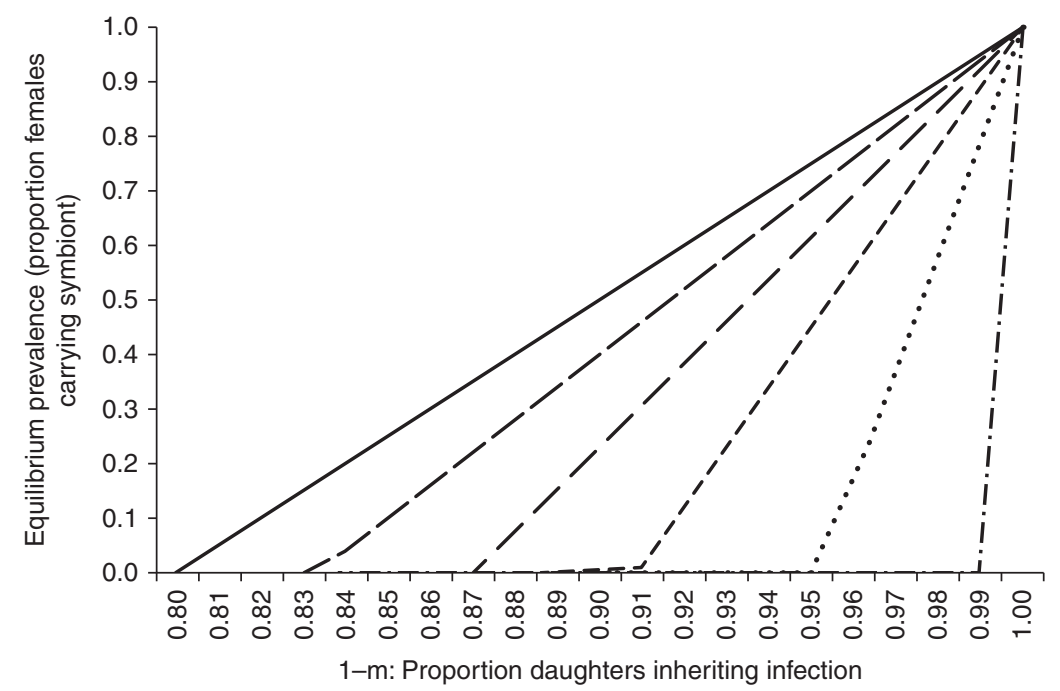

Figure 1. Equilibrium prevalence of a cost-free maternally inherited male-killing bacterium that is transmitted to a fraction $1-\mu$ of daughters, and whose daughters have increased chance of survival $1+b$ associated with the death of their brothers. Calculated from $p^{*}=[(1-\mu)(1+b)-1] / b$, following, Hurst (1991). Lines represent, from left to right, $b=0.25, b=0.2, b=0.15, b=0.1, b=0.05$, and $b=0.01$.

CMS involves mitochondrial genes that encode hydrophobic proteins, and commonly derives from genes encoding ATPase subunit. Interestingly, CMS mitochondria do not appear to have strongly deleterious effects outside of anther tissue. Notwithstanding major patterns like these, mechanisms are variable. In rice, CMS is associated with a novel mitochondrial gene whose product accumulates in anther tapetum, where it interferes with the function of a nuclear-encoded factor causing anther death (Luo et al. 2013).

The spread of CMS mitochondria relies on a compensation process, in which energy that would be dedicated to production of pollen instead is allocated to ovules (Poot 1997). Unlike heritable microbes, mitochondria have perfect vertical transmission, which can allow very high frequency of CMS types if CMS plants do not suffer from pollen limitation (McCauley and Brock 1998). The dynamics of CMS thus depend in part on pollen availability, which varies with the spatial setting of the plant (Olson et al. 2005) and whether hermaphrodite plants can selffertilize. Stabilization of polymorphism for CMS mitochondria will be seen in a metapopu- lation, as female individuals cannot found new populations (owing to lack of pollen) and can only invade existing ones (McCauley and Taylor 1997). As CMS spreads through a local population, pollen availability becomes more and more limiting, such that local patches may go extinct through CMS, again creating the conditions for CMS and wild-type mitotypes to coexist. Finally, selfing may provide a means for non-CMS individuals to avoid pollen limitation when CMS is common, and can produce a polymorphic equilibrium for CMS/wild-type mitochondria.

More recently, a shift in sex allocation from male to female function has been observed to be associated with maternally inherited fungal endophytes in Elymus virginicus grass. Although fungal endophytes are commonly considered defensive mutualists, Gorischek et al. (2013) observed that hermaphrodites infected with fungal symbionts had female-biased sex allocation; this is in contrast to the male-biased allocation pattern observed in non-endophyte-infected conspecific individuals obtained through segregation (imperfect maternal inheritance). They also showed greater vegetative propagation, again permitting symbiont maintenance. 
G.D.D. Hurst and C.L. Frost

\section{Incompatibility Associated with Symbiosis}

In the reproductive phenotypes discussed thus far, the symbiont/organelle spreads by compromising the rate at which male hosts are produced or survive, or in hermaphrodites, investment into male gametes. However, in the most common reproductive phenotype, cytoplasmic incompatibility $(\mathrm{CI})$, males are produced in normal numbers and develop to reproductive maturity in normal numbers. The symbiont has its impact in male gametogenesis, whereby it modifies sperm so that when they fuse with uninfected or differentially infected eggs, the offspring are not viable (Fig. 2). This trait is known for two symbionts, Wolbachia and Cardinium (Yen and Barr 1971; Hunter et al. 2003).

In diploids the CI phenotype is typified by mortality of both sexes. The mechanism of CI involves condensation of paternally derived chromatin in uninfected zygotes, through unknown microbial effectors (Callaini et al. 1997; Tram and Sullivan 2002; Tram et al. 2006; Landmann et al. 2009). In haplodiploid species, such as the Hymenoptera, CI results in male-biased sex ratios. Here male individuals are haploid and not the product of fertilization. Two types of CI are observed-ones in which diploid individuals are returned to full haploid status and develop as functional males (all male broods of normal size), and ones in which diploid individuals that are the product of incompatible crosses are characterized by widespread aneuploidy and death (all male broods corresponding in size to the number of males produced normally) (Breeuwer and Werren 1990; Vavre et al. 2000).

In causing cytoplasmic incompatibility, the symbiont selectively decreases the fitness of uninfected females. The degree of decrease in fitness of uninfected lineages is positively frequency-dependent-where infected males are common, uninfected females suffer more commonly. Where the symbiont is not perfectly transmitted or imposes a cost on its female bearer, there is a threshold frequency of infection that must be attained before deterministic spread of the symbiont (Fine 1978; Turelli et al. 1992). Below this frequency the CI drive phenotype is too rare to compensate for segregational loss/cost of carriage. Above this frequency it has a positive drive and will invade. The threshold frequency may be achieved through stochastic processes or through alternative drive mechanisms such as direct benefit (Fenton et al. 2011). Indeed, strains of Wolbachia that induce $\mathrm{CI}$ are also commonly known to make the host tolerant to viral attack (Hedges et al. 2008; Teixeira et al. 2008; Osborne et al. 2009), suggesting that both direct benefit and reproductive parasitism may contribute to invasion/dynamics.

Following invasion, CI strains can spread to very high prevalence. Spatial waves of advance of CI symbionts have been observed on multiple occasions (Turelli and Hoffmann 1991; Hoshizaki and Shimada 1995; Kriesner et al. 2013), indicating that there are ongoing and repeated waves of symbiont spread in insects. The ability to drive rapidly to high prevalence is useful in that it potentiates Wolbachia-mediated control-
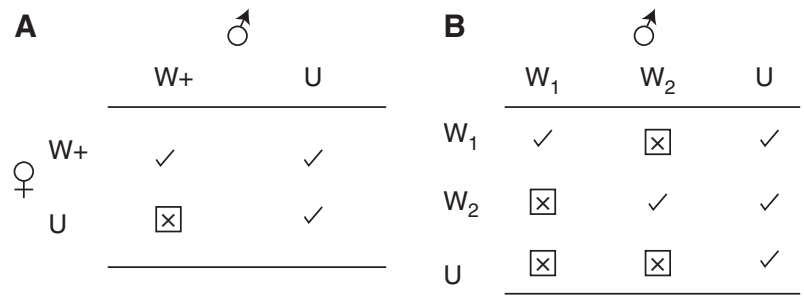

Figure 2. Cross-compatibility relationships in the presence of Wolbachia/Cardinium inducing CI. (A) Compatibility (viable zygotes) for the case of unidirectional incompatibility (one symbiont)—crosses are compatible save between infected male and uninfected female. $(B)$ Compatibility for bidirectional incompatibility, with two symbionts, $\mathrm{W}_{1}$ and $\mathrm{W}_{2}$, alongside uninfected individuals. Wolbachia-infected males are incompatible with both uninfected females and females carrying the alternate strain. 
of-vector competence following introduction (Walker et al. 2011; Yeap et al. 2011). This is currently being trialed in Aedes aegypti, into which the Wolbachia strain $w \mathrm{Mel}$ has been transinfected (Hoffmann et al. 2011). Mosquitoes carrying $w \mathrm{Mel}$ are refractory to onward transmission of dengue, and the Wolbachia also induces incompatibility, allowing its spread into populations following release. High-prevalence infections have been established in natural populations through release and CI-mediated spread, raising the possibility of interrupting dengue transmission in nature.

\section{Male Lethality/Virulence Associated with Infectious Transmission}

Selective killing of male hosts during larval phases is commonly associated with symbionts that can be both maternally and infectiously transmitted. It was first described in mosquitoes, associated with pathogenic activity of microsporidian symbionts. These symbionts are commonly vertically transmitted through females, and a subset of these are also pathological to male hosts during the fourth larval instar (Kellen et al. 1965; Hurst 1991). Spore transmission occurs through the aquatic phase and commonly requires a secondary host (e.g., copepod) (Andreadis 1991). "Late" male killing of this type has also recently been observed in a terrestrial insect, the Oriental tea tortrix, Homona magna. Here an infectious RNA virus exhibits vertical transmission in female hosts and male-specific lethality in late instar caterpillars (Morimoto et al. 2001; Nakanishi et al. 2008). Parallel limitation of virulence associated with female hosts is observed in helminth parasites of mammals. Shoop (1991) described how helminths show sex-specific tropism and pathogenesis, achieving vertical transmission through milk/accumulation in mammary tissue in females and infectious transmission through the gut in males.

Male death (in contrast to cases of embryonic male-killing) is associated with liberation of infectious spores into the environment and onward infectious transmission. Intuitively, efficient infectious transmission would select for killing of both sexes, and late male killing will be thus favored where infectious transmission rates are low. It is notable in this context that symbionts can be plastic, exhibiting vertical transmission in a growing population in which opportunities for heritable transmission are good, and infectious transmission in one at carrying capacity in which opportunities are rare (Agnew and Koella 1999; Kaltz and Koella 2003). They may also evolve to be benign where vertical transmission opportunities are common (Magalon et al. 2010).

\section{IMPACT OF CYTOPLASMIC SEX-RATIO DISTORTERS ON HOST REPRODUCTIVE ECOLOGY AND PATTERNS OF INTRAGENOMIC AND SEXUAL CONFLICT}

The spread of a symbiont that affects host sex ratio, sex allocation, or sexuality has obvious impacts on the host mating system. These include obligate loss of sex, alteration of host mating system from one of dioecy to gynodioecy, and alteration in operational sex ratio. These alterations may then impact on other conflicts associated with sexual reproduction, such as those exhibited between selfish genetic elements and their hosts, and between male and female.

\section{Symbionts and the Evolution of Obligate Asexuality}

Species and populations of haplodiploid arthropods that are obligate asexuals as a result of symbiont activity are common. Indeed, the only male specimens ever obtained in many of these species are those produced following treatment of the host with antibiotics (Stouthamer et al. 1990). However, for a symbiont alone to produce loss of sexual reproduction, it would be required to be transmitted with near perfect fidelity and to be completely accurate in inducing female development in unfertilized males. Given that symbionts commonly show some segregational loss/imperfect manipulation abilities, the transition into obligate asexuality is more commonly a complex process that involves host evolution in addition to symbiont spread.

Stouthamer et al. (2010) propose a scenario in which symbiont spread promotes the loss of 
sexual function in females. In haplodiploid species, symbiont induction of asexuality commonly involves diploidization of unfertilized male embryos. Where the symbiont becomes common and males are rare, selection can promote the production of sons through "virginity" mutations, which inhibit females from mating (Stouthamer et al. 2010). Uninfected females then produce male offspring exclusively, and infected females produce more sons if there is inefficient transmission of the symbiont or if some haploid individuals escape diploidization. The spread of virginity mutations will drive up the frequency of the asexuality-inducing symbiont, as uninfected females produce fewer daughters. The process can thus lead to the fixation of the symbiont and the loss of all sexual reproduction.

Empirical studies bear out the observation that sexual function degrades rapidly and, as predicted by the virginity hypothesis, female reproductive function is lost first. In three species (Leptopilina clavipes, Asobara japonica, and Apoanagyrus diversicornis), interpopulation variation in the presence of a symbiont that induces asexuality has allowed the functionality of males and females derived from asexual lineages to be tested. In all three cases this revealed female function to have deteriorated before male, with infected females unable to use sperm from males, while derived males were partially fertile (Pijls et al. 1996; Pannebakker et al. 2005; Kremer et al. 2009). In a variety of cases the loss of sexual traits has been shown to have a simple genetic basis (Jeong and Stouthamer 2005; Russell and Stouthamer 2011).

\section{Alteration in Mating System/Reproductive Ecology}

Symbiont-induced sex-ratio biases have been observed to alter the pattern of reproductive competition in a number of arthropod species. In Acraea encedon butterflies, 95\% of females in some populations carry a Wolbachia male killer. These populations are sex role reversed, with female reproduction limited by access to males and female-female competition for mates in evidence (Jiggins et al. 2000b). In H. bolina but- terflies, male killer prevalence across islands varies from absence (1:1 population sex ratio) to 100 females per male. Interestingly, comparison of reproductive systems between islands suggests that the impacts on host reproduction are nonlinear (Charlat et al. 2007b). Female mating rate is highest in populations in which males are moderately (but not very) scarce, with polyandry most profound at $50 \%-75 \%$ malekiller prevalence. It is believed that increases in polyandry where males are quite scarce are associated with an increased desire to remate for females that receive small spermatophores. The size of spermatophore transferred by a male declines with increasing male mating rate. Strongly female-biased sex ratios are thus associated with the transfer of small spermatophores and elevated female mating rate.

The mating system changes observed to date in the butterfly sex-ratio distorter systems are plastic - in Hypolimnas the reproductive investment patterns of males do not vary between island populations when the males are maintained in a common garden environment (Charlat et al. 2007b). This may be partly explained by the weak efficacy of selection where male killers are common (see above). However, there is evidence in feminizer-host systems for evolution of male reproductive behavior. In a comparative analysis, the male ability to fertilize multiple females was higher in two species carrying a feminizer than in five other species in which there was no feminizer present (Moreau and Rigaud 2003). This is consistent with the action of selection to partition ejaculates to enable a greater mating rate in males. Further, in Gammarus duebeni, males are sperm-limited and allocate larger ejaculates to females that do not carry feminizing symbionts (Dunn et al. 2006). Although this may be the expression of a historic preference for high-quality females, it is also consistent with adaptive preferences evolved to counter the problem of feminization.

\section{Consequences for Other Conflicts Associated with Reproduction}

Changes in mating system are very likely to alter the intensity of other conflicts. Selfish genetic 
elements, for instance, possess the highest drive in outbreeding populations. In plants the spread of cytoplasmic male sterility alters the host mating system from one of dioecy (all individuals hermaphrodite) to gynodioecy (a mix of female plants and hermaphrodites). CMS mitochondria enforce outbreeding and will reduce the rate of selfing within the population. Selfing both creates homozygosity for particular elements (preventing drive) and exposes selfish genetic elements to the damage they cause (Burt and Trivers 1998). Thus, the spread of CMS, and consequent reduction in frequency of dioecious individuals and inbreeding, may facilitate the spread of other selfish genetic elements. An expectation is that in species where selfing is possible, the presence of CMS mitochondria at high frequency would be associated with a higher load of B chromosomes and transposable elements.

The intensity of sexual conflict is likely to be affected by sex-ratio distortion. In biasing population sex ratio toward females, the conflict between male and female is likely to change in both intensity and direction. Further, the intensity of male-male precopulatory conflict will diminish. Although not examined for any particular natural case, the impact of sex-ratio manipulation on the intensity of these conflicts is well-known from experimental evolution studies (Wigby and Chapman 2004; Linklater et al. 2007). Where insects are maintained in femalebiased sex ratios, selection results in a reduction in the intensity with which males manipulate female physiology, and females are less selected to resist harm and are more susceptible to damage. Further, males are selected to partition ejaculates in the "expectation" of future mating opportunities.

\section{HOST RESPONSES TO SEX-RATIO DISTORTER ACTIVITY, AND THE EVOLUTION OF CORE FEATURES OF MALE/ FEMALE BIOLOGY}

Both sex ratio-distorting microbes and mitotypes that alter sex allocation via CMS can generate unusually strong selective forces. Where they become common, males/male gametes be- come very rare. This places them in conflict with selection on biparentally inherited nuclear genes. The nature of Fisherian selection on the sex ratio is such that modifiers of the host nuclear genome that restore male production are very strongly selected as the male host/function they rescue has very high fitness. Thus, the impact of the parasite on sex ratio makes the conflict between the parties potentially the most intense in nature.

The evolution of restoration of male function is established widely for cases of cytoplasmic male sterility induced by mitochondrial variants, in which nuclear genes are commonly termed $R f$ genes, or "restorers of fertility." Restorer genes in these systems often encode proteins with pentatricopeptide motifs, which bind RNA and function through posttranscriptional suppression of the mitochondrial transcript that would create CMS. However, alternate mechanisms of restoration exist (Luo et al. 2013). Restoration of male host survival is also known in five cases for male killing induced by heritable microbes, in which the genes are commonly termed "suppressors" (Table 4). However, the mechanisms of restoration are not known in any case. Nuclear genes that reduce the vertical transmission of feminizing microbes are also known (Rigaud and Juchault 1992).

The evolutionary dynamics of suppressor/ restorer genes are quite variable. The strength of selection will depend on the initial frequency of the distorting element, the effectiveness with which the symbionts eliminate male hosts/ function (e.g., all infected males die or are feminized vs. some), and the degree to which the nuclear gene restores phenotype (e.g., partial vs. complete restoration of male fertility). Following invasion, the equilibrium prevalence of the microbe/mitochondria and frequency of the suppressor gene depend on whether the microbe has an alternate source of "drive," as well as the "cost" of carrying a suppressor.

Where the symbionts have no alternate form of drive, a cost-free suppressor will eliminate the symbiont, whereas suppressor and male killer are expected to remain polymorphic when suppressors are costly (Randerson et al. 2000), as 
G.D.D. Hurst and C.L. Frost

\begin{tabular}{|c|c|c|c|c|}
\hline Natural host & Symbiont & Nature of suppression & Notes & References \\
\hline $\begin{array}{l}\text { Hypolimnas } \\
\text { bolina }\end{array}$ & $\begin{array}{l}\text { Wolbachia } \\
\text { wBoll }\end{array}$ & $\begin{array}{l}\text { Dominant zygotic } \\
\text { suppression of male killing }\end{array}$ & $\begin{array}{l}\text { Spatially variable; } \\
\text { evidence of recent } \\
\text { rapid spread in some } \\
\text { populations }\end{array}$ & $\begin{array}{l}\text { Hornett et al. } \\
\text { 2006, 2009; } \\
\text { Charlat et al. } \\
\text { 2007a }\end{array}$ \\
\hline $\begin{array}{l}\text { Cheilomenes } \\
\text { sexmaculata }\end{array}$ & $\begin{array}{l}\text { Hamiltonella } \\
\text { relative }\end{array}$ & $\begin{array}{l}\text { Dominant zygotic } \\
\text { suppression of male killing }\end{array}$ & $\begin{array}{l}\text { Suppressor polymorphic } \\
\text { within populations }\end{array}$ & $\begin{array}{l}\text { Majerus and } \\
\text { Majerus } 2010\end{array}$ \\
\hline $\begin{array}{l}\text { Drosophila } \\
\text { recens }\end{array}$ & Wolbachia & $\begin{array}{l}\text { Suppression suggested by } \\
\text { emergence of male killing } \\
\text { in some lines of Drosophila } \\
\text { subquinaria following } \\
\text { transfer from D. recens }\end{array}$ & & Jaenike 2007 \\
\hline Ephestia cautella & Wolbachia & $\begin{array}{l}\text { Suppression suggested by } \\
\text { emergence of male killing } \\
\text { following transfer into } \\
\text { Ephestia kuehniella }\end{array}$ & & Sasaki et al. 2002 \\
\hline $\begin{array}{l}\text { Drosophila } \\
\quad \text { prosaltans }\end{array}$ & Unknown & $\begin{array}{l}\text { Polymorphic recessive factor } \\
\text { affecting male killing }\end{array}$ & & $\begin{array}{l}\text { Cavalcanti et al. } \\
1957\end{array}$ \\
\hline $\begin{array}{l}\text { Armadillidium } \\
\quad \text { vulgare }\end{array}$ & $\begin{array}{l}\text { Wolbachia } \\
\text { wVull }\end{array}$ & $\begin{array}{l}\text { Nuclear-mediated resistance } \\
\text { to transmission of } \\
\text { feminizing symbiont }\end{array}$ & $\begin{array}{l}\text { Sex jointly determined by } \\
\text { Wolbachia presence } \\
\text { and nuclear factor } \\
\text { influencing its } \\
\text { transmission }\end{array}$ & $\begin{array}{l}\text { Rigaud and } \\
\text { Juchault } 1992\end{array}$ \\
\hline
\end{tabular}

observed in the ladybird Cheilomenes sexmaculata (Majerus and Majerus 2010). However, many symbionts have alternate drive mechanisms such that they may be retained even when suppression is complete. For instance, in $H$. bolina the suppressed male killer induces cytoplasmic incompatibility in rescued males (Hornett et al. 2008), which drives the symbiont to fixation following spread of the suppressor (Hornett et al. 2010). At this point, the suppressor becomes required for male host survival in the population and can become a fixed aspect of the host biology - albeit one whose evolutionary origins are in maintaining survival against heritable parasites alone.

The spread of suppression of male killing has been observed in natural populations of the butterfly $H$. bolina. As discussed previously, the male-killing Wolbachia in this species can attain very high prevalence. This is most obvious on Samoa, where four records over a 100year period up to 2001 reported population sex ratios of 100 females per male. This extreme sex ratio had disappeared completely by 2006
(Charlat et al. 2007a). The heritable microbe was still present in the population, but the spread of a nuclear gene that rescued male embryos (a suppressor of male killing) had restored individual and population sex ratios to parity. The spread was observed in real time over Savai'i, one of the two large islands in Independent Samoa, with population sex ratios of 100 females per male in 2005 and parity of sex ratio in 2006, 8-10 generations later.

In this system, the strength of selection at the point of origin of the suppressor is extreme. Where the sex ratio is 100 females per male, essentially all surviving male hosts will carry the suppressor in the generation after its introduction (male survival without the suppressor is negligible). Where the suppressor activity is dominant (the case in H. bolina), all males in the population are heterozygous for the suppressor element after one generation. Thus, the frequency of the suppressor increases to $25 \%$ in a single generation.

The strength of selection that suppression can engender is important for two reasons. 
First, it determines the pace of change in reproductive systems of its host-in the case of $H$. bolina, a switch from a reproductive system in which males are the "in-demand" sex to a female-limited one in potentially a single generation. Second, it determines what type of mutation can spread. Where selection is intense, mutations that would otherwise be very deleterious can actually spread. For the case of a 100:1 female/male sex ratio, a suppressor that rescued males could spread even if it reduced female host fitness by $99 \%$.

The ability to drive the spread of mutations that would otherwise be highly deleterious is perhaps one of the most interesting features of sex ratio-distorting symbionts. The intensity of conflict is such that it may drive unusual, and otherwise forbidden, alterations in the way in which male and female individuals are constructed (their sex-determination system). Although we do not know the molecular nature of suppressor mutations in any system, sex-ratio distorters interact with host sex-determination systems in multiple ways (Table 3 ), and thus an obvious avenue for selection is change in these systems. Our thesis is that the evolution of suppression of sex ratio-distorting activity will frequently involve loci associated with sex determination. Theory has proposed that the evolution of haplodiploidy and paternal genome elimination may be driven by sex ratio-distorting activity (Engelstadter and Hurst 2006; Ubeda and Normark 2006). More widely, more subtle changes in the construction of sex-determination systems are likely. We would argue that although extreme prevalence of sex-ratio distorters may be rare, they create the circumstances that can drive change in genetic systems that otherwise are rarely selected because mutations within them are otherwise deleterious. Thus, they may be a rare force that drives revolutionary changes of the type classic theory finds hard to explain.

There is already some evidence for the involvement of sex-ratio distorters in the evolution of sex-determination systems. Trivially, microbes that feminize are novel sex-determining loci. In the female heterogametic pill woodlouse, A. vulgare, spread of the feminizing agent is also associated with loss of the female-determining chromosome, such that sex becomes primarily determined by the presence/absence of Wolbachia-induced feminization. Nuclear factors that affect Wolbachia transmission are then, de facto, novel sex-determination factors, as all progeny that do not inherit Wolbachia develop as males.

Evolution of sex-determination systems has also been implied in recent study of the moth Ostrinia scapulalis. In this species $w$ Sca Wolbachia induces male killing. Male killing is associated with alteration of the splicing of the gene doublesex, such that all individuals have the female splice form of $d s x$ and those that are $\mathrm{ZZ}$ (destined to be males) die, presumably from an imbalance between sex chromosome karyotype and developmental sex (Sugimoto and Ishikawa 2012). Interestingly, when ZW individuals with Wolbachia (destined to be female) are cured using antibiotics, all male sex ratios are observed associated with male-form splicing of $d s x$ in all progeny, and the death of ZW progeny (Kageyama and Traut 2004). The investigators conclude that the Wolbachia kills through feminization and that female sex-determining factors on the $\mathrm{W}$ chromosome have degraded in the presence of the male killer, as their expression was made redundant by the Wolbachia feminization.

\section{CONFLICTS ASSOCIATED WITH CYTOPLASMIC INCOMPATIBILITY- INDUCING SYMBIONTS MAY DRIVE THE EVOLUTION OF SPERMATOGENESIS AND MATE-CHOICE PATTERNS}

The spread of cytoplasmic incompatibility-inducing symbionts produces different selection on male and female hosts. Because possession of a CI-inducing symbiont confers protection against $\mathrm{CI}$, female hosts are selected to maintain and transmit the symbiont. In contrast, the incompatibility produced by the symbiont imposes a cost on the male host. There may also be additional costs associated with the presence of a symbiont in developing sperm bundles (e.g., Snook et al. 2000). Thus, selection favors modifiers that restrict the proliferation of the 
symbiont in males and prevent entry to, and modification of, the germline (Koehncke et al. 2009). Importantly, selection on the symbiont to maintain the CI phenotype is very weak when the symbiont is common (Orr 1996), such that an antagonistic arms race is unlikely and symbiont loss thus probable. This logic creates an evolutionary trajectory where the spread of a CI symbiont is followed by host selection to prevent incompatibility, leading to the loss of the symbiont over time.

Two observations support this evolutionary trajectory. First, there is considerable variation between host species in the expression of CI by given symbiont strains (Veneti et al. 2003). Second, cytoplasmic incompatibility-inducing symbionts do not persist within a host species over long periods of evolutionary time-sibling species pairs commonly either have different infection status (infected vs. uninfected) or carry different symbiont strains that do not share a common ancestor within the host matriline in which they are currently found (Raychoudhury et al. 2009). Although there are alternate explanations for this pattern (e.g., Turelli 1994), we believe they are most likely a manifestation of selection on male hosts to prevent entry into testes/germline modification.

In the above models, males are selected not to express CI, to avoid the cost of incompatible matings. Where cross-incompatibility exists, there may also be selection on females to avoid incompatible matings (Telschow et al. 2005). An example of this process can be seen in Drosophila subquinaria. Drosophila recens and D. subquinaria are sympatric in part of their range. D. recens carries a Wolbachia that causes incompatibility in crosses to D. subquinaria males. $D$. subquinaria females show behavioral avoidance of mating with $D$. recens males, but only where the two species are sympatric (Jaenike et al. 2006). The thesis is that Wolbachia-induced cross-incompatibility selects for "reinforcement" through females' refusing incompatible matings in the zone where hybridization is possible. Indeed, the evolution of premating barriers in $D$. subquinaria in sympatry with $D$. recens also creates behavioral isolation against allopatric males of the same species.

\section{AREAS FOR FUTURE RESEARCH}

We currently understand the rationale underlying reproductive parasitism and have a good working knowledge of the population biology of these symbionts when they exhibit a single phenotype (e.g., male killing). However, the impact of these agents in natural populations is not well established. Further, there are good reasons, based on the strength of selection they produce, to believe they will drive rapid evolution in the host, but the systems under selection remain unclear. Finally, our comprehension of the biology of these symbionts has been impeded by the historical tendency to separate symbionts into "beneficial" and "reproductive parasite," whereas it is now clear that a particular symbiont can have multiple impacts, directly benefiting their host in terms of providing "function" and manipulating host reproduction to enhance their spread. Below we outline how these areas of research may be approached in future studies.

\section{The Mechanisms of Reproductive Parasite Action}

Outside of cytoplasmic male sterility, our knowledge of the mode of action of reproductive parasites is weak. There is currently little functional knowledge of the microbial effectors important in inducing phenotype, with research limited to candidate genes expressed at appropriate phases of host development (Sinkins et al. 2005). There is more (but still limited) knowledge of the host pathways with which these effectors interact (see Tables 1-3), but in no case have the host genes affecting reproductive parasite action been defined.

Study of microbial effectors has been limited by the fastidious nature of most heritable symbionts, which have generally proven recalcitrant to transgenic manipulation (despite having been shown to have recombining genomes). Study of host systems that alter symbiont action has been limited by the nonmodel nature of the species. However, it is now straightforward and cheap to obtain genome sequences for arthropods, and we expect this to allow at least the genes involved in evolved host responses to be 
identified. Further, transgenic manipulation of nonmodel species is becoming more routine and may allow more-defined functional testing.

Mechanistic work of this kind has a high priority because it will both potentiate the use of symbionts in control and also uncover the foci for selection in host species that are subject to a reproductive parasite. Currently, the nature of host responses to reproductive parasites is at the level of high-level phenotypic description: "modifies CI strength," "rescues males from death," and "prevents symbiont transmission." We should be able to establish the extent to which suppression of phenotype is associated with changes in sex determination, which genes involved in testes biology are altered to reduce symbiont impact in testes, and whether processes of oogenesis/egg formation alter to prevent symbiont transmission. This will require a mix of functional and genetic analysis.

\section{The Importance of Multiple Phenotypes}

The population and evolutionary ecology of heritable symbionts has traditionally been viewed through a single-phenotype prism-a symbiont has one impact on a host. It is clear that this is not generally true. Symbionts may combine nonprotective benefit with sex-ratio distortion (Himler et al. 2011), combine protection and reproductive manipulation (Osborne et al. 2009), and may also combine reproductive manipulation with increased susceptibility to natural enemies (Graham et al. 2012).

Symbionts that have more than one phenotypic effect will be expected to have different dynamics to our current understanding under the single-phenotype models, and the intensity of the conflict with the nuclear genome will also differ. For symbionts that produce both natural enemy resistance and reproductive parasitism, two consequences seem likely:

1. A reproductive manipulation phenotype would allow a symbiont to persist even in the absence of an ecologically contingent benefit. The advantage gained from many symbiont phenotypes is ecologically contingent- - they provide benefit only in the pres- ence of a particular parasite or in a particular abiotic environment. This renders them susceptible to loss when the pressure that produces the benefit is relaxed (Oliver et al. 2008). A symbiont with additional reproductive parasitism may be maintained indefinitely, as it additionally possesses a drive mechanism that does not rely on ecological circumstance.

2. Symbiont frequency, and thus population sex ratio, may be altered by natural enemy pressure. The link between natural enemy pressure and population sex ratio is likely to create unusual dynamics, as population sex ratio can affect population growth/density, which will have an impact on the success of the natural enemy.

The multiphenotype model also changes the intensity, and potentially the direction, of cytoplasm-nuclear conflict. First, it alters whether the host is selected to remove or retain the symbiont. Beneficial symbionts do not engender selection to remove them and may produce selection for active maintenance. Fixation and maintenance is best recognized for symbionts that make an anabolic contribution to the host (Moran et al. 1993), but is also observed for some cases of natural enemy protection (Nakabachi et al. 2013). Combining beneficial impacts with sex-ratio distortion will alter the direction of selection when a symbiont is common; the nature of Fisherian selection on the host's sex ratio is such that a symbiont that alters host sex ratio will promote the spread of modifiers that prevent sex-ratio distortion/ symbiont presence when the symbiont is at high frequency, notwithstanding any benefits of symbiont presence.

At longer evolutionary timescales, protective symbionts will clearly be vulnerable to mutation that leads to the acquisition of reproductive manipulation phenotypes. It is notable that even where "dual phenotypes" are not known, related symbiont microbes are parasitic or protective. Given the ease of movement of traits between bacteria, it is likely that it will be "easy" for symbionts to acquire additional phenotypes. 
G.D.D. Hurst and C.L. Frost

The acquisition of parasitic traits may change the direction of selection on the host from maintenance to removal, and may in part explain why protective symbionts, despite being beneficial, commonly do not have long evolutionary histories with their host. One prediction from this is that protection is likely to be maintained for longer periods of evolutionary time in host taxa in which common reproductive manipulations (e.g., male killing) are not beneficial. Conversely, protective symbiosis should be less common in groups in which reproductive parasitic phenotypes are common, as here protection does not contribute to longterm maintenance.

\section{REFERENCES}

${ }^{*}$ Reference is also in this collection.

Adachi-Hagimori T, Miura K, Stouthamer R. 2008. A new cytogenetic mechanism for bacterial endosymbiont-induced parthenogenesis in Hymenoptera. Proc Biol Sci 275: 2667-2673.

Agnew P, Koella JC. 1999. Constraints on the reproductive value of vertical transmission for a microsporidian parasite and its female-killing behaviour. J Anim Ecol 68: 1010-1019.

Andreadis TG. 1991. Epizootiology of Amblyospora conneticus (Microsporida) in field populations of the saltmarsh mosquito, Aedes cantator, and the cyclopoid copepod, Acnthocyclops vernalis. J Protozool 37: 174-182.

Arakaki N, Miyoshi T, Noda H. 2001. Wolbachia-mediated parthenogenesis in the predatory thrips Franklinothrips vespiformis (Thysanoptera: Insecta). Proc Biol Sci 268: 1011-1016.

Bentley JK, Veneti Z, Heraty J, Hurst GDD. 2007. The pathology of embryo death caused by the male-killing Spiroplasma bacterium in Drosophila nebulosa. BMC Biol 5: 9.

Bouchon D, Rigaud T, Juchault P. 1998. Evidence for widespread Wolbachia infection in isopod crustaceans: Molecular identification and host feminization. Proc Biol Sci 265: $1081-1090$

Breeuwer JAJ, Werren JH. 1990. Microorganisms associated with chromosome destruction and reproductive isolation between two insect species. Nature 346: 558-560.

Burt A, Trivers R. 1998. Selfish DNA and breeding systems in flowering plants. Proc Biol Sci 265: 141-146.

Callaini G, Dallai R, Riparbelli MG. 1997. Wolbachia-induced delay of paternal chromatin condensation doe not prevent maternal chromosomes from entering anaphase in incompatible crosses of Drosophila simulans. J Cell Sci 110: 271-280.

Cavalcanti AGL, Falcao DN, Castro LE. 1957. "Sex-ratio" in Drosophila prosaltans-A character due to interaction between nuclear genes and cytoplasmic factors. Am Nat 91: $327-329$.
Charlat S, Hornett EA, Fullard JH, Davies N, Roderick GK, Wedell N, Hurst GDD. 2007a. Extraordinary flux in sex ratio. Science 317: 214-214.

Charlat S, Reuter M, Dyson EA, Hornett EA, Duplouy A, Davies N, Roderick GK, Wedell N, Hurst GDD. 2007b. Male-killing bacteria trigger a cycle of increasing male fatigue and female promiscuity. Curr Biol 17: 273-277.

Cosmides L, Tooby J. 1981. Cytoplasmic inheritance and intragenomic conflict. J Theor Biol 89: 83-129.

Dannowski J, Flor M, Telschow A, Hammerstein P. 2009. The effect of sibmating on the infection dynamics of male-killing bacteria. Evolution 63: 2525-2534.

Dedeine F, Vavre F, Fleury F, Loppin B, Hochberg ME, Boulétreau M. 2001. Removing symiobitic Wolbachia bacteria specifically inhibits oogenesis in a parasitic wasp. Proc Natl Acad Sci 98: 6247-6252.

Dunn AM, Andrews T, Ingrey H, Riley J, Wedell N. 2006. Strategic sperm allocation under parasitic sex-ratio distortion. Biol Lett 2: 78-80.

Duron O, Hurst G. 2013. Arthropods and inherited bacteria: From counting the symbionts to understanding how symbionts count. BMC Biol 11: 45.

Dyson EA, Hurst GDD. 2004. Persistence of an extreme sexratio bias in a natural population. Proc Natl Acad Sci 101: 6520-6523.

Elnagdy S, Majerus MEN, Handley LJL. 2011. The value of an egg: Resource reallocation in ladybirds (Coleoptera: Coccinellidae) infected with male-killing bacteria. J Evol Biol 24: 2164-2172.

Engelstadter J, Hurst GDD. 2006. Can maternally transmitted endosymbionts facilitate the evolution of haplodiploidy? J Evol Biol 19: 194-202.

Fenton A, Johnson KN, Brownlie JC, Hurst GDD. 2011. Solving the Wolbachia paradox: Modeling the tripartite interaction between host, Wolbachia, and a natural enemy. Am Nat 178: 333-342.

Ferree PM, Avery A, Azpurua J, Wilkes T, Werren JH. 2008. A bacterium targets maternally inherited centrosomes to kill males in Nasonia. Curr Biol 18: 1409-1414.

Fine PEM. 1978. On the dynamics of symbiote-dependent cytoplasmic incompatibility in culicine mosquitoes. J Invertebr Pathol 31: 10-18.

Giorgini M, Monti MM, Caprio E, Stouthamer R, Hunter MS. 2009. Feminization and the collapse of haplodiploidy in an asexual parasitoid wasp harboring the bacterial symbiont Cardinium. Heredity (Edinb) 102: 365371.

Giorgini M, Bernardo U, Monti MM, Nappo AG, Gebiola M. 2010. Rickettsia symbionts cause parthenogenetic reproduction in the parasitoid wasp Pnigalio soemius (Hymenoptera: Eulophidae). Appl Environ Microbiol 76: 2589-2599.

Gorischek AM, Afkhami ME, Seifert EK, Rudgers JA. 2013. Fungal symbionts as manipulators of plant reproductive biology. Am Nat 181: 562-570.

Gottlieb Y, Zchori-Fein E, Werren JH, Karr TL. 2002. Diploidy restoration in Wolbachia-infected Muscidifurax uniraptor (Hymenoptera: Pteromalidae). J Invertebr Pathol 81: $166-174$.

Graham RI, Grzywacz D, Mushobozi WL, Wilson K. 2012. Wolbachia in a major African crop pest increases suscept- 
ibility to viral disease rather than protects. Ecol Lett 15: 993-1000.

Groenenboom MAC, Hogeweg P. 2002. Space and the persistence of male-killing endosymbionts in insect populations. Proc Biol Sci 269: 2509-2518.

Hamilton PT, Perlman SJ. 2013. Host defense via symbiosis in Drosophila. PLoS Pathog 9: e1003808.

Hedges LM, Brownlie JC, O’Neill SL, Johnson KN. 2008. Wolbachia and virus protection in insects. Science 322: 702-702.

Himler AG, Adachi-Hagimori T, Bergen JE, Kozuch A, Kelly SE, Tabashnik BE, Chiel E, Duckworth VE, Dennehy TJ, Zchori-Fein E, et al. 2011. Rapid spread of a bacterial symbiont in an invasive whitefly is driven by fitness benefits and female bias. Science 332: 254-256.

Hiroki M, Kato Y, Kamito T, Miura K. 2002. Feminization of genetic males by a symbiotic bacterium in a butterfly, Eurema hecabe (Lepidoptera: Pieridae). Naturwissenschaften 89: 167-170.

Hoffmann AA, Montgomery BL, Popovici J, Iturbe-Ormaetxe I, Johnson PH, Muzzi F, Greenfield M, Durkan M, Leong YS, Dong Y, et al. 2011. Successful establishment of Wolbachia in Aedes populations to suppress dengue transmission. Nature 476: 454-457.

Hornett EA, Charlat S, Duplouy AMR, Davies N, Roderick GK, Wedell N, Hurst GDD. 2006. Evolution of male killer suppression in a natural population. PLoS Biol 4: 16431648.

Hornett EA, Duplouy AMR, Davies N, Roderick GK, Wedell N, Hurst GDD, Charlat S. 2008. You can't keep a good parasite down: Evolution of a male-killer suppressor uncovers cytoplasmic incompatibility. Evolution 62: 12581263.

Hornett EA, Charlat S, Wedell N, Jiggins CD, Hurst GDD 2009. Rapidly shifting sex ratio across a species range. Curr Biol 19: 1628-1631.

Hornett EA, Engelstadter J, Hurst GDD. 2010. Hidden cytoplasmic incompatibility alters the dynamics of malekiller/host interactions. J Evol Biol 23: 479-487.

Hoshizaki S, Shimada T. 1995. PCR-based detection of Wolbachia, cytoplasmic microorganisms, infected in natural populations of Laodelphax striatellus (Homoptera: Delphacidae) in central Japan: Has the distribution of Wolbachia spread recently? Insect Mol Biol 4: 237-243.

Huigens ME, Hohmann CL, Luck RF, Gort G, Stouthamer R. 2004. Reduced competitive ability due to Wolbachia infection in the parasitoid wasp Trichogramma kaykai. Entomol Exp Appl 110: 115-123.

Hunter MS, Perlman SJ, Kelly SE. 2003. A bacterial symbiont in the Bacteroidetes induces cytoplasmic incompatibility in the parasitoid wasp Encarsia pergandiella. Proc Biol Sci 270: $2185-2190$.

Hurst LD. 1991. The incidences and evolution of cytoplasmic male killers. Proc Biol Sci 244: 91-99.

Hurst GDD, Majerus MEN, Walker LE. 1993. The importance of cytoplasmic male killing elements in natural populations of the two spot ladybird, Adalia bipunctata (Linnaeus) (Coleoptera: Coccinellidae). Biol J Linn Soc 49: 195-202.

Hurst LD, Atlan A, Bengtsson B. 1996. Genetic conflicts. Q Rev Biol 71: 317-364.
Hurst GDD, Jiggins FM, von der Schulenburg JHG, Bertrand D, West SA, GoriachevaII, Zakharov IA, Werren JH, Stouthamer R, Majerus MEN. 1999a. Male-killing Wolbachia in two species of insect. Proc Biol Sci 266: 735-740.

Hurst GDD, von der Schulenburg JHG, Majerus TMO, Bertrand D, Zakharov IA, Baungaard J, Volkl W, Stouthamer R, Majerus MEN. 1999b. Invasion of one insect species, Adalia bipunctata, by two different male-killing bacteria. Insect Mol Biol 8: 133-139.

Hurst GDD, Johnson AP, von der Schulenburg JHG, Fuyama Y. 2000. Male-killing Wolbachia in Drosophila: A temperature-sensitive trait with a threshold bacterial density. Genetics 156: 699-709.

Jaenike J. 2007. Spontaneous emergence of a new Wolbachia phenotype. Evolution 61: 2244-2252.

Jaenike J, Dyer KA, Cornish C, Minhas MS. 2006. Asymmetrical reinforcement and Wolbachia infection in Drosophila. PLoS Biol 4: 1852-1862.

Jahnke M, Smith JE, Dubuffet A, Dunn AM. 2013. Effects of feminizing microsporidia on the masculinizing function of the androgenic gland in Gammarus duebeni. J Invertebr Pathol 112: 146-151.

Jeong G, Stouthamer R. 2005. Genetics of female functional virginity in the parthenogenesis-Wolbachia infected parasitoid wasp Telenomus nawai (Hymenoptera: Scelionidae). Heredity (Edinb) 94: 402-407.

Jiggins FM, Hurst GDD, Jiggins CD, von der Schulenburg JHG, Majerus MEN. 2000a. The butterfly Danaus chrysippus is infected by a male-killing Spiroplasma bacterium. Parasitology 120: 439-446.

Jiggins FM, Hurst GDD, Majerus MEN. 2000b. Sex-ratiodistorting Wolbachia causes sex-role reversal in its butterfly host. Proc Biol Sci 267: 69-73.

Jiggins FM, Randerson JP, Hurst GDD, Majerus MEN. 2002. How can sex ratio distorters reach extreme prevalences? Male-killing Wolbachia are not suppressed and have nearperfect vertical transmission efficiency in Acraea encedon. Evolution 56: 2290-2295.

Kageyama D, Traut W. 2004. Opposite sex-specific effects of Wolbachia and interference with the sex determination of its host Ostrinia scapulalis. Proc Biol Sci 271: 251-258.

Kaltz O, Koella JC. 2003. Host growth conditions regulate the plasticity of horizontal and vertical transmission in Holospora undulata, a bacterial parasite of the protozoan Paramecium caudatum. Evolution 57: 1535-1542.

Kellen WR, Chapman HC, Clark TB, Lindegren JE. 1965. Host-parasite relationships of some Thelohania from mosquitoes (Nosematidae: Microsporidia). J Invertebr Pathol 7: 161-166.

Kobayashi Y, Telschow A. 2010. Cytoplasmic feminizing elements in a two-population model: Infection dynamics gene flow modification, and the spread of autosomal suppressors. J Evol Biol 23: 2558-2568.

Koehncke A, Telschow A, Werren JH, Hammerstein P. 2009. Life and death of an influential passenger: Wolbachia and the evolution of CI-modifiers by their hosts. PLoS ONE 4: e4425.

Koivisto RKK, Braig HK. 2003. Microorganisms and parthenogenesis. Biol J Linn Soc 79: 43-58. 
G.D.D. Hurst and C.L. Frost

Koop JL, Zeh DW, Bonilla MM, Zeh JA. 2009. Reproductive compensation favours male-killing Wolbachia in a livebearing host. Proc Biol Sci 276: 4021-4028.

Kremer N, Charif D, Henri H, Bataille M, Prevost G, Kraaijeveld K, Vavre F. 2009. A new case of Wolbachia dependence in the genus Asobara: Evidence for parthenogenesis induction in Asobara japonica. Heredity (Edinb) 103: 248-256.

Kriesner P, Hoffmann AA, Lee SF, Turelli M, Weeks AR. 2013. Rapid sequential spread of two Wolbachia variants in Drosophila simulans. PLoS Pathog 9: e1003607.

Kubo T, Kitazaki K, Matsunaga M, Kagami H, Mikami T. 2011. Male sterility-inducing mitochondrial genomes: How do they differ? Crit Rev Plant Sci 30: 378-400.

Landmann F, Orsi GA, Loppin B, Sullivan W. 2009. Wolbachia-mediated cytoplasmic incompatibility is associated with impaired histone deposition in the male pronucleus. PLoS Pathog 5: e1000343.

Laven H. 1951. Crossing experiments with Culex strains. Evolution 5: 370-375.

Lawson ET, Mousseau TA, Klaper R, Hunder MD, Werren JH. 2001. Rickettsia associated with male-killing in a buprestid beetle. Heredity (Edinb) 86: 497-505.

Lewis D. 1941. Male sterility in natural populations of hermaphrodite plants: The equilibrium between females and hermaphrodites to be expected with different types of inheritance. New Phytol 40: 56-63.

Linklater JR, Wertheim B, Wigby S, Chapman T. 2007. Ejaculate depletion patterns evolve in response to experimental manipulation of sex ratio in Drosophila melanogaster. Evolution 61: 2027-2034.

Luo DP, Xu H, Liu ZL, Guo JX, Li HY, Chen LT, Fang C, Zhang QY, Bai M, Yao N, et al. 2013. A detrimental mitochondrial-nuclear interaction causes cytoplasmic male sterility in rice. Nat Genet 45: 573-577.

Lus YY. 1947. Some rules of reproduction in populations of Adalia bipunctata: II. Non-male strains in populations. Dokl Akad Nauk SSSR 57: 951-954.

Magalon H, Nidelet T, Martin G, Kaltz O. 2010. Host growth conditions influence experimental evolution of life history and virulence of a parasite with vertical and horizontal transmission. Evolution 64: 2126-2138.

Magni GE. 1953. "Sex-ratio": A non-Mendelian character in Drosophila bifasciata. Nature 172: 81.

Majerus TMO, Majerus MEN. 2010. Intergenomic arms races: Detection of a nuclear rescue gene of male-killing in a ladybird. PLoS Pathog 6: e1000987.

Malogolowkin C. 1958. Maternally inherited "sex-ratio" condition in Drosophila willistoni and Drosophila paulistorum. Genetics 43: 274-286.

Martin J, Chong T, Ferree PM. 2013. Male killing Spiroplasma preferentially disrupts neural development in the Drosophila melanogaster embryo. PLoS ONE 8: e79368.

McCauley DE, Brock MT. 1998. Frequency-dependent fitness in Silene vulgaris, a gynodioecious plant. Evolution 52: $30-36$.

McCauley DE, Taylor DR. 1997. Local population structure and sex ratio: Evolution in gynodioecious plants. Am Nat 150: $406-419$.
Moran NA, Munson MA, Baumann P, Ishikawa H. 1993. A molecular clock in endosymbiotic bacteria is calibrated using the insect hosts. Proc Biol Sci 253: 167-171.

Moran NA, McCutcheon JP, Nakabachi A. 2008. Genomics and evolution of heritable bacterial symbionts. Annu Rev Genet 42: 165-190.

Moreau J, Rigaud T. 2003. Variable male potential for reproduction: High male mating capacity as an adaptation to prevent parasite-induced excess of females. Proc Biol Sci 270: $1535-1540$

Moreau J, Bertin A, Caubet Y, Rigaud T. 2001. Sexual selection in an isopod with Wolbachia-induced sex reversal: Males prefer real females. J Evol Biol 14: 388-394.

Moret Y, Juchault P, Rigaud T. 2001. Wolbachia endosymbiont responsible for cytoplasmic incompatibility in a terrestrial crustacean. Heredity (Edinb) 86: 325-332.

Morimoto S, Nakai M, Ono A, Kunimi Y. 2001. Late malekilling phenomenon found in a Japanese population of the oriental tea tortrix, Homona magnanima (Lepidoptera: Tortricidae). Heredity (Edinb) 87: 435-440.

Nakabachi A, Ueoka R, Oshima K, Teta R, Mangoni A, Gurgui M, Oldham NJ, van Echten-Deckert G, Okamura K, Yamamoto K, et al. 2013. Defensive bacteriome symbiont with a drastically reduced genome. Curr Biol 23: 1478-1484.

Nakanishi K, Hoshino M, Nakai M, Kunimi Y. 2008. Novel RNA sequences associated with late male killing in $\mathrm{Ho}$ mona magnanima. Proc Biol Sci 275: 1249-1254.

Narita S, Kageyama D, Nomura M, Fukatsu T. 2007. Unexpected mechanism of symbiont-induced reversal of insect sex: Feminizing Wolbachia continuously acts on the butterfly Eurema hecabe during larval development. Appl Environ Microbiol 73: 4332-4341.

Negri I, Franchini A, Gonella E, Daffonchio D, Mazzoglio PJ, Mandrioli M, Alma A. 2009. Unravelling the Wolbachia evolutionary role: The reprogramming of the host genomic imprinting. Proc Biol Sci 276: 2485-2491.

Oliver KM, Campos J, Moran NA, Hunter MS. 2008. Population dynamics of defensive symbionts in aphids. Proc Biol Sci 275: 293-299.

Olson MS, McCauley DE, Taylor D. 2005. Genetics and adaptation in structured populations: Sex ratio evolution in Silene vulgaris. Genetica 123: 49-62.

Orr MR. 1996. Host manipulation by Wolbachia is a neutral trait within single populations. Anim Behav 51: 11831185.

Osborne SE, Leong YS, O’Neill SL, Johnson KN. 2009. Variation in antiviral protection mediated by different Wolbachia strains in Drosophila simulans. PLoS Pathog 5: e1000656.

Pannebakker BA, Pijnacker LP, Zwaan BJ, Beukeboom LW. 2004. Cytology of Wolbachia-induced parthenogenesis in Leptopilina clavipes (Hymenoptera: Figitidae). Genome 47: $299-303$

Pannebakker BA, Schidlo NS, Boskamp GJF, Dekker L, Van Dooren TJM, Beukeboom LW, Zwaan BJ, Brakefield PM, Van Alphen JJM. 2005. Sexual functionality of Leptopilina clavipes (Hymenoptera: Figitidae) after reversing Wolbachia-induced parthenogenesis. J Evol Biol 18: 1019-1028. 
Pijls JWAM, van Steenbergen HJ, van Alphen JJM. 1996. Asexuality cured: The relations and differences between sexual and asexual Apoanagyrus diversicornis. Heredity (Edinb) 76: 506-513.

Poot P. 1997. Reproductive allocation and resource compensation in male-sterile and hermaphroditic plants of Plantago lanceolata (Plantaginaceae). Am J Bot 84: 1256.

Randerson JP, Smith NGC, Hurst LD. 2000. The evolutionary dynamics of male-killers and their hosts. Heredity (Edinb) 84: 152-160.

Raychoudhury R, Baldo L, Oliveira D, Werren JH. 2009. Modes of acquisition of Wolbachia: Horizontal transfer, hybrid introgression, and codivergence in the Nasonia species complex. Evolution 63: 165-183.

Rigaud T, Juchault P. 1992. Genetic control of the vertical transmission of a cytoplasmic sex factor in Armadillidium vulgare. Heredity (Edinb) 68: 47-52.

Riparbelli MG, Giordano R, Ueyama M, Callaini G. 2012. Wolbachia-mediated male killing is associated with defective chromatin remodeling. PLoS ONE 7: e30045.

Russell JE, Stouthamer R. 2011. The genetics and evolution of obligate reproductive parasitism in Trichogramma pretiosum infected with parthenogenesis-inducing Wolbachia. Heredity (Edinb) 106: 58-67.

Sanada-Morimura S, Matsumura M, Noda H. 2013. Male killing caused by a Spiroplasma symbiont in the small brown planthopper, Laodelphax striatellus. Heredity 104: $821-829$.

Sasaki T, Kubo T, Ishikawa H. 2002. Interspecific transfer of Wolbachia between two lepidopteran insects expressing cytoplasmic incompatibility: A Wolbachia variant naturally infecting Cadra cautella causes male killing in Ephestia kuehniella. Genetics 162: 1313-1319.

Segoli M, Stouthamer R, Stouthamer CM, Rugman-Jones P, Rosenheim JA. 2013. The effect of Wolbachia on the lifetime reproductive success of its insect host in the field. J Evol Biol 26: 2716-2720.

Shoop WL. 1991. Vertical transmission of helminths: Hypobiosis and amphiparatenesis. Parasitol Today 7: 51-54.

Shull HF. 1948. An all-female strain of lady beetles with reversion to normal sex ratios. Am Nat 82: 241-251.

Simmonds HW. 1923a. All female families of Hypolimnas bolina L., bred in Fiji by H. W. Simmonds. Proc R Entomol Soc Lond 1923: $\mathrm{x}$-xii.

Simmonds HW. 1923b. Families of Hypolimnas bolina L. bred from known female parents from different Fijian islands. Trans R Entomol Soc Lond 1923: 651-662.

Simmonds HW. 1926. Sex ratio of Hypolimnas bolina L., in Viti Levu, Fiji. Proc R Entomol Soc Lond 1: 29-32.

Simmonds HW. 1927. Sex-ratio of Hypolimnas bolina L. in Viti Levu, Fiji. Proc R Entomol Soc Lond 2: 5-10.

Simmonds HW. 1928. Mr. H. W. Simmonds' conclusion that all-female-producing females form a persistent strain in Suva. Proc R Entomol Soc Lond 3: 43-44.

Simmonds HW. 1930. Further notes on Hypolimnas bolina L. in Fiji. Proc R Entomol Soc Lond 5: 75-77.

Simon J-C, Boutin S, Tsuchida T, Koga R, Le Gallic J-F, Frantz A, Outreman Y, Fukatsu T. 2011. Facultative symbiont infections affect aphid reproduction. PLOS ONE 6: e21831.
Sinkins SP, Walker T, Lynd AR, Steven AR, Makepeace BL, Godfray HCJ, Parkhill J. 2005. Wolbachia variability and host effects on crossing type in Culex mosquitoes. Nature 436: $257-260$.

Snook RR, Cleland SY, Wolfner MF, Karr TL. 2000. Offsetting effects of Wolbachia infection and heat shock on sperm production in Drosophila simulans: Analysis of fecundity, fertility and accessory gland proteins. Genetics 155: $167-178$.

Stouthamer R, Kazmer D. 1994. Cytogenetics of microbeassociated parthenogenesis and its consequence for gene flow in Trichogramma wasps. Heredity (Edinb) 73: 317327.

Stouthamer R, Luck RF. 1993. Influence of microbe-associated parthenogenesis on the fecundity of Trichogramma deion and T. pretiosum. Entomol Exp Appl 67: 183192.

Stouthamer R, Luck RF, Hamilton WD. 1990. Antibiotics cause parthenogenetic Trichogramma (Hymenoptera, Trichogrammatidae) to revert to sex. Proc Natl Acad Sci 87: 2424-2427.

Stouthamer R, Russell JE, Vavre F, Nunney L. 2010. Intragenomic conflict in populations infected by parthenogenesis inducing Wolbachia ends with irreversible loss of sexual reproduction. BMC Evol Biol 10: 229.

Sugimoto TN, Ishikawa Y. 2012. A male-killing Wolbachia carries a feminizing factor and is associated with degradation of the sex-determining system of its host. Biol Lett 8: $412-415$.

Sugimoto TN, Fujii T, Kayukawa T, Sakamoto H, Ishikawa Y. 2012. Expression of a doublesex homologue is altered in sexual mosaics of Ostrinia scapulalis moths infected with Wolbachia. Insect Biochem Mol Biol 40: 847-854.

Taylor DR. 1990. Evolutionary consequences of cytoplasmic sex-ratio distorters. Evol Ecol 4: 235-248.

Teixeira L, Ferreira A, Ashburner M. 2008. The bacterial symbiont Wolbachia induces resistance to RNA viral infections in Drosophila melanogaster. Plos Biol 12: $2753-$ 2763.

Telschow A, Hammerstein P, Werren JH. 2005. The effect of Wolbachia versus genetic incompatibilities on reinforcement and speciation. Evolution 59: 1607-1619.

Terry RS, Smith JE, Sharpe RG, Rigaud T, Littlewood DTJ, Ironside JE, Rollinson D, Bouchon D, MacNeil C, Dick JTA. 2004. Widespread vertical transmission and associated host sex-ratio distortion within the eukaryotic phylum Microspora. Proc Biol Sci 271: 1783-1789.

Timmermans MTN, Ellers J. 2009. Wolbachia endosymbiont is essential for egg hatching in a parthenogenetic arthropod. Evol Ecol 23: 931-942.

Tram U, Sullivan W. 2002. Role of delayed nuclear envelope breakdown and mitosis in Wolbachia-induced cytoplasmic incompatibility. Science 296: 1124-1126.

Tram U, Fredrick K, Werren JH, Sullivan W. 2006. Paternal chromosome segregation during the first mitotic division determines Wolbachia-induced cytoplasmic incompatibility phenotype. J Cell Sci 119: 3655-3663.

Turelli M. 1994. Evolution of incompatibility-inducing microbes and their hosts. Evolution 48: 1500-1513. 
G.D.D. Hurst and C.L. Frost

Turelli M, Hoffmann AA. 1991. Rapid spread of an inherited incompatibility in California Drosophila. Nature 353: $440-442$.

Turelli M, Hoffmann AA, McKechnie SW. 1992. Dynamics of cytoplasmic incompatibility and mtDNA variation in natural Drosophila simulans populations. Genetics 132: $713-723$.

Ubeda F, Normark BB. 2006. Male killers and the origins of paternal genome elimination. Theor Popul Biol 70: $511-$ 526.

Vandel A. 1941. Recherches sur la génétique et la sexualité des Isopodes terrestre: VI. Les phénomènes de monologénie chez Onisocides [Research on genetics and sexuality of the terrestrial isopods: VI. The phenomena of unisexual broods in Oniscidea]. Bull Biol de la France et Belgique 75: 316-363.

Vavre F, Fleury F, Varaldi J, Fouillet P, Boulétreau M. 2000. Evidence for female mortality in Wolbachia-mediated cytoplasmic incompatibility in haplodiploid insects: Epidemiologic and evolutionary consequences. Evolution 54: $191-200$.

Veneti Z, Clark ME, Zabalou S, Karr TL, Savakis B, Bourtzis K. 2003. Cytoplasmic incompatibility and sperm cyst infection in different Drosophila/host associations. Genetics 164: 545-552.

Veneti Z, Bentley JK, Koana T, Braig HR, Hurst GDD. 2005. A functional dosage compensation complex required for male killing in Drosophila. Science 307: 1461-1463.

* Wade MJ. 2014. Paradox of mother's curse and the maternally provisioned offspring microbiome. Cold Spring Harb Perspect Biol doi: 10.1101/cshperspect.a017541.

Walker T, Johnson PH, Moreira LA, Iturbe-Ormaetxe I, Frentiu FD, McMeniman CJ, Leong YS, Dong Y, Axford
J, Kriesner P, et al. 2011. The wMel Wolbachia strain blocks dengue and invades caged Aedes aegypti populations. Nature 476: 450-453.

Weeks AR, Breeuwer JAJ. 2001. Wolbachia induced parthenogenesis in a genus of phytophagous mite. Proc Biol Sci 268: 2245-2251.

Weeks AR, Marec F, Breeuwer JAJ. 2001. A mite species that consists entirely of haploid females. Science 292: 24792482.

Werren JH. 1987. The coevolution of autosomal and cytoplasmic sex ratio factors. J Theor Biol 124: 317-334.

Werren JH, Hurst GDD, Zhang W, Breeuwer JAJ, Stouthamer R, Majerus MEN. 1994. Rickettsial relative associated with male killing in the ladybird beetle (Adalia bipunctata). J Bacteriol 176: 388-394.

Wigby S, Chapman T. 2004. Female resistance to male harm evolves in response to manipulation of sexual conflict. Evolution 58: 1028-1037.

Williamson DL, Poulson DF. 1979. Sex ratio organisms (Spiroplasmas) of Drosophila. In The mycoplasmas (ed. Whitcomb RF, Tully JG), pp. 175-208. Academic, New York.

Yeap HL, Mee P, Walker T, Weeks AR, O’Neill SL, Johnson P, Ritchie SA, Richardson KM, Doig C, Endersby NM, et al. 2011. Dynamics of the "popcorn" Wolbachia infection in outbred Aedes aegypti informs prospects for mosquito vector control. Genetics 187: 583-595.

Yen JH, Barr AR. 1971. New hypothesis of the cause of cytoplasmic incompatibility in Culex pipiens. Nature 232: $657-658$.

Zeh DW, Zeh JA, Bonilla MM. 2005. Wolbachia, sex ratio bias and apparent male killing in the harlequin beetle riding pseudoscorpion. Heredity (Edinb) 95: 41-49. 


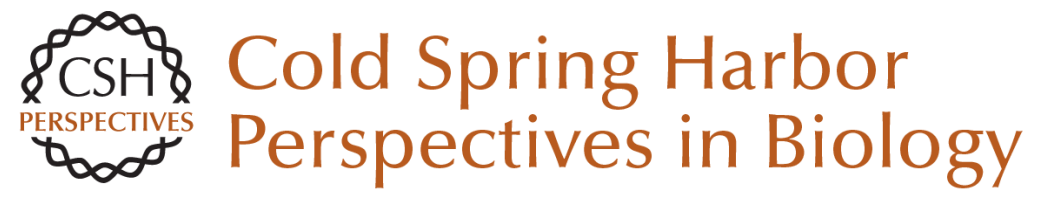

\section{Reproductive Parasitism: Maternally Inherited Symbionts in a Biparental World}

Gregory D.D. Hurst and Crystal L. Frost

Cold Spring Harb Perspect Biol 2015; doi: 10.1101/cshperspect.a017699

Subject Collection The Genetics and Biology of Sexual Conflict

Mechanisms and Evidence of Genital

Coevolution: The Roles of Natural Selection, Mate Choice, and Sexual Conflict

Patricia L.R. Brennan and Richard O. Prum

The Evolution of Sexually Antagonistic

Phenotypes

Jennifer C. Perry and Locke Rowe

Reproductive Parasitism: Maternally Inherited Symbionts in a Biparental World Gregory D.D. Hurst and Crystal L. Frost

Sex-Biased Gene Expression and Sexual Conflict throughout Development

Fiona C. Ingleby, Ilona Flis and Edward H. Morrow

Human Homosexuality: A Paradigmatic Arena for Sexually Antagonistic Selection?

Andrea Camperio Ciani, Umberto Battaglia and Giovanni Zanzotto

Sexual Conflict Arising from Extrapair Matings in Birds

Alexis S. Chaine, Robert Montgomerie and Bruce E. Lyon

Sexual Conflict and Seminal Fluid Proteins: A Dynamic Landscape of Sexual Interactions Laura K. Sirot, Alex Wong, Tracey Chapman, et al.

Conflict on the Sex Chromosomes: Cause, Effect, and Complexity

Judith E. Mank, David J. Hosken and Nina Wedell
Infanticide as Sexual Conflict: Coevolution of

Male Strategies and Female Counterstrategies Ryne A. Palombit

Copulatory Wounding and Traumatic Insemination

Klaus Reinhardt, Nils Anthes and Rolanda Lange

Sexual Conflict in Hermaphrodites Lukas Schärer, Tim Janicke and Steven A. Ramm

Sexual Conflict and Sperm Competition Dominic A. Edward, Paula Stockley and David J. Hosken

Sexually Antagonistic Zygotic Drive: A New Form of Genetic Conflict between the Sex

Chromosomes

Urban Friberg and William R. Rice

Sex Chromosome Drive

Quentin Helleu, Pierre R. Gérard and Catherine

Montchamp-Moreau

Is Sexual Conflict an "Engine of Speciation"? Sergey Gavrilets

Sexual Cannibalism as a Manifestation of Sexual Conflict

Jutta M. Schneider

For additional articles in this collection, see http://cshperspectives.cshlp.org/cgi/collection/

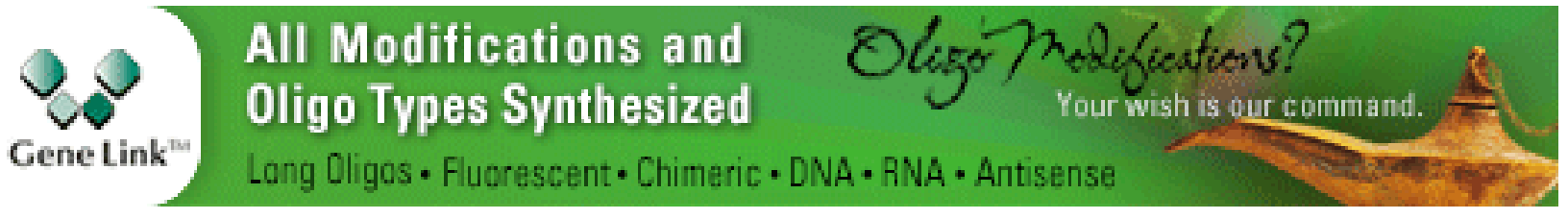


For additional articles in this collection, see http://cshperspectives.cshlp.org/cgi/collection/

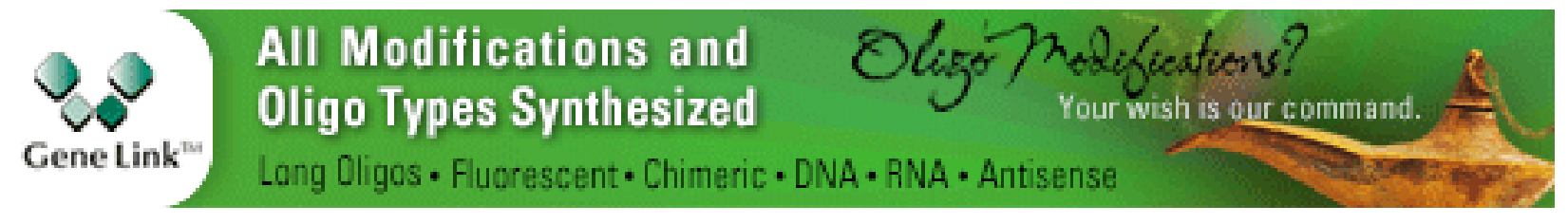

Copyright @ 2015 Cold Spring Harbor Laboratory Press; all rights reserved 